\title{
Lactobacillus suntoryeus Cachat and Priest 2005 is a later synonym of Lactobacillus helveticus (Orla-Jensen 1919) Bergey et al. 1925 (Approved Lists 1980)
}

\author{
Sabri M. Naser, ${ }^{1,2}$ Karen E. Hagen, ${ }^{3}$ Marc Vancanneyt, ${ }^{2}$ Ilse Cleenwerck, $^{2}$ \\ Jean Swings ${ }^{1,2}$ and Thomas A. Tompkins ${ }^{3}$ \\ 1,2 Laboratory of Microbiology ${ }^{1}$ and BCCM ${ }^{\mathrm{TM}} / \mathrm{LMG}$ Bacteria Collection ${ }^{2}$, Ghent University, \\ K. L. Ledeganckstraat 35, Ghent 9000, Belgium \\ ${ }^{3}$ Institut Rosell Inc., Research and Development, 6100 Royalmount Ave, Montreal, Quebec, \\ Canada, H4P 2R2
}

Correspondence

Sabri M. Naser

Sabri.Naser@Ugent.be

\begin{abstract}
Strain R0052, isolated from a North American dairy starter culture, was initially identified as Lactobacillus acidophilus based on phenotypic analyses. However, upon sequencing the $16 \mathrm{~S}$ rRNA gene, it became clear that the isolate was very highly related to Lactobacillus suntoryeus, Lactobacillus helveticus and Lactobacillus gallinarum, as similarities ranging from $99 \cdot 3$ to $99 \cdot 8 \%$ were observed. As an initial screening test to investigate the relatedness of strain R0052 and reference strains of $L$. suntoryeus, $L$. helveticus and $L$. gallinarum, the partial sequences for the genes encoding the alpha subunit of ATP synthase (atpA), RNA polymerase alpha subunit (rpoA), phenylalanyl-tRNA synthase alpha subunit ( $p h e S)$, the translational elongation factor Tu (tuf), a surface-layer protein $(s / p)$ and the Hsp60 chaperonins ( $g r o E L)$ were determined and they revealed high relatedness between all of the strains. The determination of the 16S-23S rRNA internally transcribed spacer (ITS) sequences revealed 98-3-100\% similarity between L. suntoryeus and $L$. helveticus strains. SDS-PAGE of whole-cell proteins did not distinguish between these species. Fluorescent amplified fragment length polymorphism (FAFLP) could distinguish between these taxa, but they still constituted a single cluster within the L. acidophilus group. Finally, DNA-DNA hybridization experiments between strain R0052 and the type strains of $L$. helveticus and $L$. suntoryeus yielded reassociation values above $70 \%$ and confirmed that these names are synonyms.
\end{abstract}

Lactobacillus suntoryeus, isolated from Japanese and Scottish malt whisky distilleries, has been described recently by Cachat \& Priest (2005). The type strain SA ${ }^{\mathrm{T}}$ ( = LMG 22464 ${ }^{\mathrm{T}}$ ), strain Y10 and strain M4 (= LMG 22465) had identical 16S rRNA gene sequences and the topology of the phylogenetic tree confirmed that they were members of the Lactobacillus acidophilus group. The $16 \mathrm{~S}$ rRNA gene sequences of these strains showed $99 \cdot 3$ and $98 \cdot 1 \%$ similarity to Lactobacillus helveticus and Lactobacillus gallinarum, respectively. DNADNA hybridization values of less than $43 \%$ were observed

Published online ahead of print on 7 October 2005 as DOI 10.1099/ijs.0.64001-0.

Abbreviations: FAFLP, fluorescent amplified fragment length polymorphism; ITS, internally transcribed spacer.

The GenBank/EMBL/DDBJ accession numbers for the sequences reported in this paper are: 16S rRNA partial gene sequences for strains LMG 11445 and R0052, DQ123572 and DQ123580; atpA partial gene sequences for strains LMG 6413', LMG 22464 ${ }^{\top}$, RO052, LMG 6904 $^{\top}$, LMG $^{\top}$ 9435', LMG 11445, LMG 13522 and LMG 22465, AM086429-AM086431, AM157788-AM157792, respectively; pheS partial gene sequences for strains LMG 6413', LMG 22464 ${ }^{\top}$, R0052, LMG 6904 ${ }^{\top}$, LMG 9435', LMG 18225, LMG 11445, LMG 11447, LMG 13522 and LMG 22465,

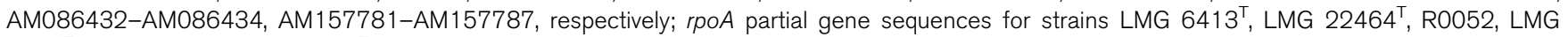
9435', LMG 18225, LMG 6904', LMG 11445, LMG 11447, LMG 13522 and LMG 22465, AM086435-AM086437, AM157774-AM157780, respectively; tuf partial gene sequences for strains LMG 11445, LMG 22465 and R0052, DQ123571, DQ123578 and DQ123584, respectively; groEL partial gene sequences for strains LMG 11445, LMG 22464', LMG 22465 and R0052, DQ123573, DQ123576, DQ123579 and DQ123581, respectively; 16S-23S ITS gene sequences for strains LMG 11445, LMG 6413' ${ }^{\top}$, LMG 22464 ${ }^{\top}$, LMG 22465 and R0052, DQ123570, DQ123574, DQ123575, DQ123577 and DQ123582, respectively; s/p partial gene sequence for strain R0052, DQ123583.

Additional neighbour-joining trees based on the sequences of six genes and ITS sequences are available as supplementary figures in IJSEM Online. 
between the distillery strains and their closest neighbours, L. helveticus and L. gallinarum. Further, genomic and phenotypic data demonstrated that $L$. suntoryeus represented a novel species (Cachat \& Priest, 2005).

L. helveticus, isolated from sour milk, cheese starter cultures and cheese, was first described by Orla-Jensen in 1919 (Kandler \& Weiss, 1986; Hammes \& Vogel, 1995). L. helveticus represents a homofermentative, thermophilic lactic acid bacterium, which ferments hexoses to lactic acid (Holzapfel et al., 2001). L. helveticus is an important food-associated species adapted to sour whey and is traditionally used in the manufacture of Swiss-type and long-ripened Italian cheeses, such as Emmental, Gruyère and Provolone. In particular, L. helveticus is the most prevalent species recovered from natural lactic starter cultures used to produce typical Italian cheeses (Giraffa et al., 2000; Stiles \& Holzapfel, 1997). L. helveticus is distinct from Lactobacillus delbrueckii, the type species of the genus Lactobacillus, but is closely related to Lactobacillus acidophilus with respect to DNADNA hybridization, biochemical features and 16S rRNA gene sequences (Kandler \& Weiss, 1986; Klein et al., 1998). Accordingly, L. acidophilus, L. gallinarum, Lactobacillus crispatus and L. helveticus form a cluster of closely related species.

Strain R0052 was isolated from a North American dairy starter culture in March 1990 by Institut Rosell, Canada, and was initially typed as L. acidophilus based on its API profile and D-lactate production. In addition to strain R0052, several reference strains of L. helveticus, LMG $6413^{\mathrm{T}}$, LMG 11445, LMG 11447, LMG 11448, LMG 13522 and LMG 18225, were selected for further comparative study. Two L. suntoryeus strains, LMG $22464^{\mathrm{T}}$ and LMG 22465 (supplied by F. Priest), were included in the study. All strains studied were cultivated and maintained on de Man, Rogosa and Sharpe (MRS) medium and incubated anaerobically at $37^{\circ} \mathrm{C}$, unless indicated otherwise.

The 16S rRNA genes of R0052 and LMG 11445 were obtained using primers Lb16a (Guan et al., 2003), Lb16b (5' CGGTGTGTACAAGGCCCG-3'), 16Smidford (degenerate form of 16Smidfor, Requena et al., 2002; 5'-GKCYGYWACTGACGCTGAG- $3^{\prime}$ ) and 16Smidrev (5'-GCRTGGACTACCAGGGTATC-3') at an annealing temperature of $56^{\circ} \mathrm{C}$ with $0.2 \mathrm{mM}$ dNTPs, 1 pmol primer $\mu \mathrm{l}^{-1}$ and $0.05 \mathrm{U}$ Taq DNA polymerase $\mu \mathrm{l}^{-1}$, which were used to amplify genomic DNA extracted by bead beating (Walter et al., 2001). PCR products were purified using a QIAGEN PCR purification kit following the manufacturer's instructions. Sequencing of the purified PCR products was performed with an Amersham DYEnamic ET terminator cycle sequencing kit following the guidelines provided by the DNA Sequencing Facility at the Biotechnology Research Institute (Montreal, Canada). The R0052 sequence was compared with the $16 \mathrm{~S}$ rRNA gene sequences of $L$. helveticus, L. gallinarum and L. suntoryeus as available on GenBank and with the sequence obtained for strain LMG 11445 and strain R0052 was found to share $99 \cdot 8 \%$ similarity with $L$. suntoryeus strains LMG $22464^{\mathrm{T}}$ and LMG 22465. The sequence was also $99.5 \%$ similar to the $16 \mathrm{~S}$ rRNA gene sequence of $L$. gallinarum ATCC $33199^{\mathrm{T}}$ and shared $99 \cdot 3$ and $99 \cdot 7 \%$ similarity with $L$. helveticus strains LMG $6413^{\mathrm{T}}$ and LMG 11445, suggesting that strain R0052 could belong to any of these three species.

The simultaneous use of several housekeeping genes in bacterial taxonomy offers a higher resolution than 16S rRNA gene sequence data at the species level as it integrates information from different molecular markers from throughout the bacterial chromosome (Stackebrandt et al., 2002; Zeigler, 2003). The partial sequences for the genes encoding the alpha subunit of ATP synthase (atpA), RNA polymerase alpha subunit $(r p o A)$ and phenylalanyl-tRNA synthase alpha subunit (pheS) were used as an initial screening test to investigate the relatedness between the L. helveticus strains LMG 6413 ${ }^{\mathrm{T}}$, LMG 11445, LMG 11447, LMG 13522 and LMG 18225, the L. suntoryeus strains LMG $22464^{\mathrm{T}}$ and LMG 22465, L. gallinarum LMG $9435^{\mathrm{T}}$ and strain R0052. Primer sequences, amplification conditions and sequencing reactions were performed as described by Naser et al. (2005a, b). Neighbour-joining trees of the atpA, rpoA and pheS gene sequences revealed high relatedness between the investigated strains of $L$. helveticus and $L$. suntoryeus, with at least $99.5 \%$ similarity in the atpA, rpoA and pheS gene sequences. Significantly lower values, in the range of 95-98\%, were found with the nearest neighbour $L$. gallinarum, indicating that L. helveticus and L. suntoryeus may represent the same species (see Supplementary Figs S1, S2 and S3 in IJSEM Online). Strain R0052 showed high levels of similarity to strains of both $L$. helveticus and L. suntoryeus ( $>99 \cdot 5 \%$ atpA, rpoA and pheS gene sequence similarities).

The translational elongation factor Tu (tuf) and Hsp60 chaperonin ( $g r o E L)$ genes were also analysed. DNA from strain R0052, L. helveticus LMG 11445 and L. suntoryeus LMG 22465 was extracted by bead beating as described above for $16 \mathrm{~S}$ rRNA gene sequence analysis. Amplification and sequencing of tuf genes, using primers TUF-1 and TUF-2, was performed as described by Ventura et al. (2003). A comparison was made with the sequences available from GenBank for the strains L. helveticus LMG $6413^{\mathrm{T}}, L$. suntoryeus LMG $22464^{\mathrm{T}}$ and L. gallinarum LMG $9435^{\mathrm{T}}$. The L. suntoryeus, L. helveticus and L. gallinarum strains were highly similar ( $>98 \%$ sequence similarity; see Supplementary Fig. S4). Strain R0052 had $>98.8 \%$ similarity with the L. helveticus and L. suntoryeus strains and $98 \cdot 1 \%$ similarity to the L. gallinarum type strain. DNA from strains R0052, L. helveticus LMG 11445 and L. suntoryeus strains LMG $22464^{\mathrm{T}}$ and LMG 22465 was further used as template for groEL gene sequencing using primers groEL1F (5'-GAAGGNATGAAGAAYGTBAC-3') and groEL1R (5'AATGTHCCACGVATCTTG-3') at an annealing temperature of $47^{\circ} \mathrm{C}$ with $0.2 \mathrm{mM}$ dNTPs, 1 pmol primer $\mu \mathrm{l}^{-1}$ and $0.05 \mathrm{U}$ Taq DNA polymerase $\mu \mathrm{l}^{-1}$. A comparison was made with the sequences available from GenBank for 
L. helveticus LMG $6413^{\mathrm{T}}$ and L. gallinarum LMG $9435^{\mathrm{T}}$. The partial sequence of groEL of strain R0052 showed >99\% similarity with the sequences of the investigated $L$. helveticus and $L$. suntoryeus strains and a significantly lower similarity $(96 \%)$ with the L. gallinarum type strain (see Supplementary Fig. S5 in IJSEM Online). The tuf and groEL sequences indicated that $L$. suntoryeus and $L$. helveticus cannot be differentiated and, in particular, groEL sequence analysis demonstrated a more distant relatedness of the species to their nearest neighbour, L. gallinarum.

The 16S-23S rRNA internally transcribed spacer (ITS) sequences were amplified from template DNA (prepared as described above) from strain R0052, L. helveticus strains LMG $6413^{\mathrm{T}}$ and LMG 11445 and L. suntoryeus strains LMG $22464^{\mathrm{T}}$ and LMG 22465 with primers 16-1Ad (a degenerate form of 16-1A, 5'-GBYGGARTCGCTAGTAATCG-3') and 23-1B as described in Tannock et al. (1999). A comparison was made with the sequences available from GenBank for the L. gallinarum type strain. It was found that strain R0052 shared $100 \%$ similarity with both L. suntoryeus strains and 99 and $98.5 \%$ similarity with $L$. helveticus strains LMG $6413^{\mathrm{T}}$ and LMG 11445 , respectively. The first 60 nucleotides of the L. gallinarum ITS sequence available from GenBank showed only $91.7 \%$ similarity with R0052, supporting the indications that strain R0052 is a member of one of the closely related species $L$. suntoryeus or L. helveticus (Supplementary Fig. S6 in IJSEM Online).

Lactobacillus sp. strain R0052, L. helveticus strains LMG 6413 ${ }^{\mathrm{T}}$, LMG 11445, LMG 11447, LMG 11448, LMG 13522 and LMG 18225 and two L. suntoryeus strains, LMG $22464^{\mathrm{T}}$ and LMG 22465, were further investigated using PAGE of whole-cell proteins. Whole-cell protein extracts were prepared and SDS-PAGE was performed as described by Pot et al. (1994). Densitometric analysis, normalization and interpolation of protein profiles and numerical analysis were performed by using the GELCOMPAR software package, versions 3.1 and 4.0, respectively (Applied Maths). The five $L$. helveticus strains, the type strain of $L$. suntoryeus and strain R0052 constituted a homogeneous cluster, with the exception being L. suntoryeus LMG 22465 (Fig. 1). This aberrant position may be due to strain-specific variations of dominant protein bands in the molecular mass range of 35-42 kDa, perhaps due to differences in the surface layer (S-layer) proteins located on the outer surface of the bacterial cell (Boot et al., 1996).
A more detailed study was performed on the S-layer proteins. Partial sequences of the S-layer protein (or slp) of strain R0052 were obtained with primers Usl-1 and Usl-2 (Hagen et al., 2005). The PCR product was purified as described above for 16S rRNA gene sequencing and ligated into cloning vector pGEM-T Easy (Promega) which was transformed into Escherichia coli JM109 competent cells (Promega) according to the manufacturer's instructions. Clones were grown on Luria-Bertani (LB) agar containing $100 \mu \mathrm{g}$ ampicillin $\mathrm{ml}^{-1}, 80 \mu \mathrm{g} \mathrm{X}-\mathrm{Gal} \mathrm{ml}{ }^{-1}$ (5-bromo-4chloro-3-indolyl-beta-D-galactopyranoside) and $0.5 \mathrm{mM}$ IPTG (isopropyl-beta-D-thiogalactopyranoside) at $37^{\circ} \mathrm{C}$ overnight. Eight blue transformants were picked and grown in $2 \mathrm{YT}$ broth $(1.6 \%$ tryptone, $0.8 \%$ yeast extract and $85.6 \mathrm{mM} \mathrm{NaCl}$; Sambrook et al., 1989) overnight at $37^{\circ} \mathrm{C}$ with vigorous aeration. A $0.5 \mathrm{ml}$ sample of each clone was stocked in LB with $50 \%$ glycerol and stored at $-80^{\circ} \mathrm{C}$. The remainder was used for plasmid DNA extraction using the alkaline lysis method with polyethylene glycol (PEG) precipitation (Sambrook et al., 1989). Clones were screened by sequencing the purified plasmid DNA using primers T7 and Sp6. One slp gene sequence was obtained and the clone was fully sequenced in both directions using primers R0052slp-1 (5' -TAACGATACTAGCAATGATG-3') and R0052slp-2 (5' -CCGTATTGGTCCAAACTTAC-3'). The sequence of the extreme $3^{\prime}$ end of the gene was obtained with primers R0052CTD-5 (5'-AATGGTAAGTCAACTGTTGT$\left.3^{\prime}\right)$ and R0052CTD-6 (5'-AAGTTTTCAACTCTAACG-3') at an annealing temperature of $44^{\circ} \mathrm{C}$ with $0.2 \mathrm{mM}$ dNTPs, 1 pmol primer $\mu \mathrm{l}^{-1}$ and $0.05 \mathrm{U}$ Taq DNA polymerase $\mu^{-1}$. The PCR product was purified and sequenced as described above. A large DNA sequence divergence was observed among S-layer protein genes of strain R0052, L. helveticus strains LMG $6413^{\mathrm{T}}$ and LMG 11445 and two L. suntoryeus strains, LMG $22464^{\mathrm{T}}$ and LMG 22465 (see Supplementary Fig. S7 in IJSEM Online). This is not surprising, given the location and function of S-layer proteins, which are highly expressed and form a paracrystalline coat outside of the bacterial cell wall (Sleytr \& Sara, 1997). S-layer proteins are thought to mediate tissue adherence (Sillanpää et al., 2000; Antikainen et al., 2002) and may also affect selective nutrient transport (Sára \& Sleytr, 2000) or protect from proteases (Lortal, 1993). As these proteins are surface-exposed and play a role in survival and adaptation in the environment, their primary sequence differs considerably between members of the same species (Boot et al., 1996) as can be seen in SDS-PAGE of proteins (Fig. 1). Conversely, Ventura et al.

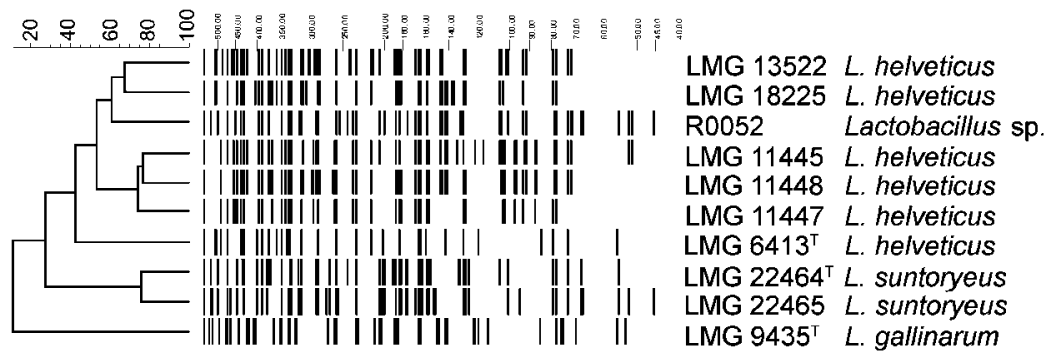

Fig. 1. SDS-PAGE protein profiles and the corresponding dendrogram derived from the UPGMA average linkage of correlation coefficients $r$ (expressed for convenience as a percentage value) for $L$. helveticus and $L$. suntoryeus strains and related reference strains. 
(2000) observed very high similarity between other S-layer proteins of $L$. helveticus.

The same set of strains analysed by 1D SDS-PAGE was further investigated using fluorescent amplified fragment length polymorphism (FAFLP) fingerprinting of whole genomes. FAFLP fingerprinting was performed as described by Vancanneyt et al. (2005). The FAFLP fingerprints of these strains were compared with reference profiles of lactic acid bacteria taxa as currently available in the database developed at Ghent University, Belgium. FAFLP analysis revealed a high similarity between the L. helveticus and L. suntoryeus strains. Fig. 2 shows a dendrogram in which strain R0052 grouped with $L$. helveticus reference strains and was separated from $L$. suntoryeus strains and $L$. gallinarum. However, both taxa (L. helveticus and $L$. suntoryeus) still constituted a single cluster within the $L$. acidophilus group (data not shown). FAFLP randomly samples the whole bacterial genome and better differentiates closely related strains (i.e. the interpretation of intraspecies relationships) (Dellaglio et al., 2005).

In a final step, DNA-DNA hybridizations were performed between strain R0052, L. suntoryeus LMG $22464^{\mathrm{T}}$ and $L$. helveticus strains LMG $6413^{\mathrm{T}}$ and LMG 11445. L. acidophilus LMG $9433^{\mathrm{T}}$ and L. gallinarum LMG $9435^{\mathrm{T}}$ were used as controls. Genomic DNA was prepared according to the protocol of Pitcher et al. (1989) with the following modifications: the washed cell pellet was resuspended and lysed in a buffer (10 mM Tris/HCl, 100 mM EDTA, $\mathrm{pH} 8 \cdot 0$ ) that contained RNase $\left(200 \mu \mathrm{g} \mathrm{ml}^{-1}\right.$; Sigma), mutanolysin (100 $\mathrm{U} \mathrm{ml}^{-1}$; Sigma) and lysozyme $\left(25 \mathrm{mg} \mathrm{ml}^{-1}\right.$; SERVA) for $1 \mathrm{~h}$ at $37^{\circ} \mathrm{C}$. The microplate method was used as described by Ezaki et al. (1989) and Goris et al. (1998), using an HTS7000 Bio Assay Reader (Perkin Elmer) for the fluorescence measurements. Biotinylated DNA was hybridized with unlabelled single-stranded DNA, which was bound non-covalently to microplate wells. Hybridizations were performed at $36^{\circ} \mathrm{C}$ in hybridization mixture $(2 \times \mathrm{SSC}$, $5 \times$ Denhardt's solution, $2.5 \%$ dextran sulfate, $50 \%$ formamide, $100 \mu \mathrm{g}$ denatured salmon sperm DNA ml ${ }^{-1}$, $1250 \mathrm{ng}$ biotinylated probe DNA ml${ }^{-1}$ ). Reciprocal reactions (e.g. $\mathrm{A} \times \mathrm{B}$ and $\mathrm{B} \times \mathrm{A}$ ) were performed. The $\mathrm{DNA}-$ DNA reassociation values reported were the mean values of a minimum of four hybridization experiments, including the reciprocal reactions. L. helveticus (LMG $6413^{\mathrm{T}}$ and LMG 11445 ), strain R0052 and L. suntoryeus LMG $22464^{\mathrm{T}}$ showed high DNA-DNA binding values (70-90\%), indicating clearly that both taxa belong to the same genospecies. In particular, a DNA-DNA hybridization value of $78 \%$ was found between L. helveticus LMG $6413^{\mathrm{T}}$ and $L$. suntoryeus LMG $22464^{\mathrm{T}}$, whereas hybridization values of $80 \%$ were obtained between strain R0052 and the type strains of $L$. helveticus and $L$. suntoryeus. The latter results contradict those obtained by Cachat \& Priest (2005), who reported a low hybridization value of less than $43 \%$ between the type strains of these taxa.

Growth characteristics and biochemical features were investigated for strains R0052, L. gallinarum LMG $9435^{\mathrm{T}}$, $L$. helveticus strains LMG $6413^{\mathrm{T}}$ and LMG 11445 and $L$. suntoryeus strains LMG $22464^{\mathrm{T}}$ and LMG 22465. The strains were grown on MRS agar after $24 \mathrm{~h}$ incubation at $37^{\circ} \mathrm{C}$ under aerobic conditions. Carbohydrate fermentation tests were carried out using API50 CHL galleries following the manufacturer's instructions (bioMérieux) and the results are presented in Table 1 . In particular, the L. gallinarum type strain, LMG $9435^{\mathrm{T}}$, utilized D-raffinose and glycogen, whereas the other strains did not. The L. suntoryeus strains did not ferment galactose and the L. helveticus strains did not ferment sucrose, aesculin, salicin or cellobiose. Strain R0052 was able to metabolize all of these carbohydrates as well as arbutin and $\beta$-gentiobiose, and showed the broadest utilization of carbohydrates among the strains tested.

Samples were prepared for API ZYM analysis following the manufacturer's instructions (bioMérieux) except that the cells were resuspended in $0.85 \% \mathrm{NaCl}$ and no mineral oil was added. The strips were incubated for the time stated in the manufacturer's instructions. Strain R0052 and the $L$. suntoryeus isolates were identified as L. acidophilus. All the strains tested negative for alkaline phosphatase, esterase lipase (C8), lipase (C14), trypsin, $\alpha$-chymotrypsin, $\beta$ glucuronidase, $N$-acetyl- $\beta$-glucosaminidase, $\alpha$-mannosidase and $\alpha$-fucosidase activities. All the strains had leucine, valine and cystine arylamidase activities and acid phosphatase, naphthol-AS-BI-phosphohydrolase and $\beta$-galactosidase activities. Weak esterase (C4) activity was observed for all strains, but only the L. gallinarum strain showed $\alpha$ galactosidase activity. Differences in glucosidase production were observed: R0052 and the L. suntoryeus strains had $\alpha$-glucosidase and $\beta$-glucosidase activities whereas the L. helveticus strains did not.

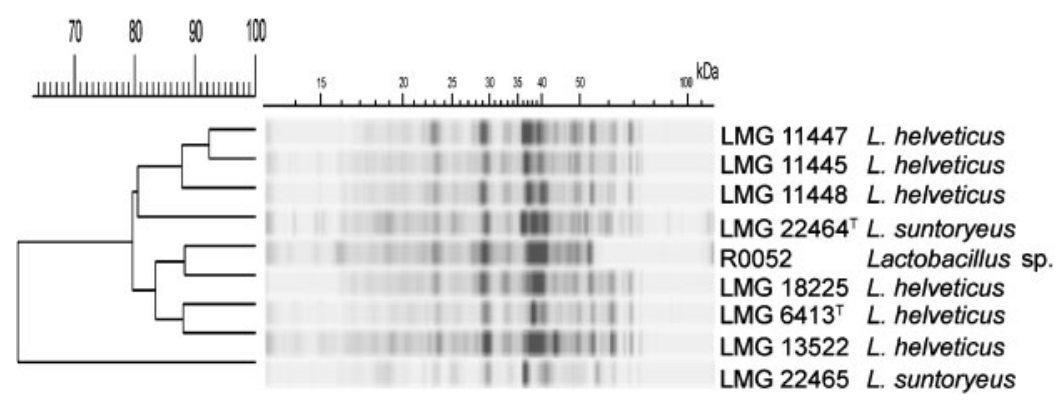

Fig. 2. FAFLP patterns and the corresponding dendrogram, derived from the UPGMA linkage of Dice coefficients (expressed as a percentage value for convenience) of $L$. helveticus and $L$. suntoryeus strains and related reference strains. 
Table 1. Differential phenotypic features between strains R0052, L. helveticus strains LMG $6413^{\top}$ and LMG 11445, L. suntoryeus strains LMG $22464^{\top}$ and LMG 22465 and L. gallinarum LMG $9435^{\top}$

All strains tested positive for utilization of D-glucose and D-mannose. Other sugars were not metabolized by the assayed strains. No growth was observed in the absence of sugars. -, Negative; +, positive; \pm , weak reaction.

\begin{tabular}{|c|c|c|c|c|c|c|}
\hline \multirow[t]{2}{*}{ Characteristic } & \multirow[t]{2}{*}{ R0052 } & \multicolumn{2}{|c|}{ L. helveticus } & \multicolumn{2}{|c|}{ L. suntoryeus } & \multirow{2}{*}{$\frac{\text { L. gallinarum }}{\text { LMG } 9435^{\mathrm{T}}}$} \\
\hline & & LMG $6413^{T}$ & LMG 11445 & LMG $22464^{\mathrm{T}}$ & LMG 22465 & \\
\hline $\mathrm{N}$-Acetylglucosamine & + & + & \pm & - & + & + \\
\hline Aesculin & + & - & - & + & + & + \\
\hline Amygdalin & + & - & - & - & + & - \\
\hline Arbutin & + & - & - & - & - & - \\
\hline Cellobiose & + & - & - & + & + & + \\
\hline D-Fructose & + & + & - & + & + & + \\
\hline Galactose & + & + & + & - & - & + \\
\hline$\beta$-Gentiobiose & + & - & - & - & - & - \\
\hline Glycogen & - & - & - & - & - & + \\
\hline Lactose & + & + & - & - & - & + \\
\hline Maltose & + & + & - & + & + & + \\
\hline D-Raffinose & - & - & - & - & - & + \\
\hline Salicin & + & - & - & + & + & + \\
\hline Sucrose & + & - & - & + & + & + \\
\hline Trehalose & + & + & - & - & - & - \\
\hline
\end{tabular}

The strains were also tested for the production of $\mathrm{D}-$ and $\mathrm{L}-$ lactic acid and acetate by the D-/L-lactic acid kit (Megazyme) and the acetic acid kit (Megazyme). For the lactic acid assays, an overnight culture of each strain was centrifuged at $3000 \mathrm{~g}$ for $10 \mathrm{~min}$ and the supernatant was collected. The $\mathrm{pH}$ of the supernatant was adjusted to a value between 8 and 10, then the supernatant was incubated at room temperature for $15 \mathrm{~min}$ and then assayed with the kit according to the manufacturer's instructions. For the acetate assay, the same procedure was performed except that the $\mathrm{pH}$ was adjusted to $7 \cdot 5$. All strains tested produced $\mathrm{D}$ - and L-lactic acid at a ratio of approximately $45: 55$, with the exception of R0052 which had a ratio of $60: 40$. Additionally, all strains produced small amounts of acetate (mean $0 \cdot 29 \mathrm{~g} \mathrm{l}^{-1}$ ).

Taken together, these phenotypic data support the observation that sugar utilization is insufficient for the identification of closely related lactobacilli (Fujisawa et al., 1992), thus necessitating DNA-DNA hybridization tests.

On the basis of the evidence presented, it is proposed that the species L. suntoryeus and L. helveticus be united under the same name. As a rule of priority (Rules 38 and 42 of the Bacteriological Code; Lapage et al., 1992), the name L. helveticus should be retained and strains of L. suntoryeus should be reclassified as such.

\section{Acknowledgements}

S. M. N acknowledges a PhD scholarship from the Palestinian Ministry of Education and Higher Education. J. S. acknowledges grants from the
Fund for Scientific Research (FWO), Belgium. The assistance of Manon Lalumière at the Biotechnology Research Institute DNA Sequencing Facility was greatly appreciated. The phenotypic analyses were performed by Catia Simard and Jocelyn Belvis. Special thanks to Fergus Priest (Heriot Watt University, Edinburgh) for supplying strain M4.

\section{References}

Antikainen, J., Anton, L., Sillanpää, J. \& Korhonen, T. K. (2002). Domains in the S-layer protein CbsA of Lactobacillus crispatus involved in adherence to collagens, laminin and lipoteichoic acids and in self-assembly. Mol Microbiol 46, 381-394.

Bergey, D. H., Harrison, F. C., Breed, R. S., Hammer, B. W. \& Huntoon, F. M. (editors) (1925). Bergey's Manual of Determinative Bacteriology, 2nd edn. Baltimore: Williams \& Wilkins.

Boot, H. J., Kolen, C. P., Pot, B., Kersters, K. \& Pouwels, P. H. (1996). The presence of two S-layer-protein-encoding genes is conserved among species related to Lactobacillus acidophilus. Microbiology 142, 2375-2384.

Cachat, E. \& Priest, F. G. (2005). Lactobacillus suntoryeus sp. nov., isolated from malt whisky distilleries. Int J Syst Evol Microbiol 55, 31-34.

Dellaglio, F., Felis, G. E., Castioni, A., Torriani, S. \& Germond, J. E. (2005). Lactobacillus delbrueckii subsp. indicus subsp. nov., isolated from Indian dairy products. Int J Syst Evol Microbiol 55, 401-404.

Ezaki, T., Hashimoto, Y. \& Yabuuchi, E. (1989). Fluorometric deoxyribonucleic acid-deoxyribonucleic acid hybridization in microdilution wells as an alternative to membrane filter hybridization in which radioisotopes are used to determine genetic relatedness among bacterial strains. Int J Syst Bacteriol 39, 224-229. 
Fujisawa, T., Benno, Y., Yaeshima, T. \& Mitsuoka, T. (1992). Taxonomic study of the Lactobacillus acidophilus group, with recognition of Lactobacillus gallinarum sp. nov. and Lactobacillus johnsonii sp. nov. and synonymy of Lactobacillus acidophilus group A3 (Johnson et al. 1980) with the type strain of Lactobacillus amylovorus (Nakamura 1981). Int J Syst Bacteriol 42, 487-491.

Giraffa, G., Gatti, M., Rossetti, L., Senini, L. \& Neviani, E. (2000). Molecular diversity within Lactobacillus helveticus as revealed by genotypic characterization. Appl Environ Microbiol 66, 1259-1265.

Goris, J., Suzuki, K., De Vos, P., Nakase, T. \& Kersters, K. (1998). Evaluation of a microplate DNA-DNA hybridization method compared with the initial renaturation method. Can J Microbiol 44, 1148-1153.

Guan, L. L., Hagen, K. E., Tannock, G. W., Korver, D. R., Fasenko, G. M. \& Allison, G. E. (2003). Detection and identification of Lactobacillus species in crops of broilers of different ages by using PCR-denaturing gradient gel electrophoresis and amplified ribosomal DNA restriction analysis. Appl Environ Microbiol 69, 6750-6757.

Hagen, K. E., Guan, L. L., Tannock, G. W., Korver, D. R. \& Allison, G. E. (2005). Detection, characterization, and in vitro and in vivo expression of genes encoding S-proteins in Lactobacillus gallinarum strains isolated from chicken crops. Appl Environ Microbiol 71, 6633-6643.

Hammes, W. P. \& Vogel, R. F. (1995). The genus Lactobacillus. In The Lactic Acid Bacteria, vol. 2, The Genera of Lactic Acid Bacteria, pp. 19-54. Edited by B. J. B. Wood \& W. H. Holzapfel. London: Blackie Academic \& Professional.

Holzapfel, W. H., Haberer, P., Geisen, R., Bjorkroth, J. \& Schillinger, U. (2001). Taxonomy and important features of probiotic microorganisms in food and nutrition. Am J Clin Nutr 73, 365S-373S.

Kandler, O. \& Weiss, N. (1986). Genus Lactobacillus Beijerinck 1901. In Bergey's Manual of Systematic Bacteriology, vol. 2, pp. 1209-1234. Edited by P. H. A. Sneath, N. S. Mair, M. E. Sharpe \& J. G. Holt. Baltimore: Williams \& Wilkins.

Klein, G., Pack, A., Bonaparte, C. \& Reuter, G. (1998). Taxonomy and physiology of probiotic lactic acid bacteria. Int J Food Microbiol 41, 103-125.

Lapage, S. P., Sneath, P. H. A., Lessel, E. F., Skerman, V. B. D., Seeliger, H. P. R. \& Clark, W. A. (editors) (1992). International Code of Nomenclature of Bacteria (1990 Revision). Bacteriological Code. Washington, DC: American Society for Microbiology.

Lortal, S. (1993). Crystalline surface-layers of the genus Lactobacillus. In Advances in Bacterial Paracrystalline Surface Layers, pp. 57-65. Edited by T. J. Beveridge \& S. F. Koval. New York: Plenum.

Naser, S., Thompson, F. L., Hoste, B., Gevers, D., Vandemeulebroecke, K., Cleenwerck, I., Thompson, C. C., Vancanneyt, M. \& Swings, J. (2005a). Phylogeny and identification of enterococci by atpA gene sequence analysis. J Clin Microbiol 43, 2224-2230.

Naser, S. M., Thompson, F. L., Hoste, B., Gevers, D., Dawyndt, P., Vancanneyt, M. \& Swings, J. (2005b). Application of multilocus sequence analysis (MLSA) for rapid identification of Enterococcus species based on rpoA and pheS genes. Microbiology 151, 2141-2150.
Pitcher, D. G., Saunders, N. A. \& Owen, R. G. (1989). Rapid extraction of bacterial genomic DNA with guanidium thiocyanate. Lett Appl Microbiol 8, 151-156.

Pot, B., Vandamme, P. \& Kersters, K. (1994). Analysis of electrophoretic whole-organism protein fingerprints. In Modern Microbial Methods. Chemical Methods in Prokaryotic Systematics, pp. 493-521. Edited by M. Goodfellow \& A. G. O’Donnell. Chichester: Wiley.

Requena, T., Burton, J., Matsuki, T., Munro, K., Simon, M. A., Tanaka, R., Watanabe, K. \& Tannock, G. W. (2002). Identification, detection, and enumeration of human Bifidobacterium species by PCR targeting the transaldolase gene. Appl Environ Microbiol 68, 2420-2427.

Sambrook, J., Fritsch, E. \& Maniatis, T. (1989). Molecular Cloning: $a$ Laboratory Manual, 2nd edn. Cold Spring Harbor, NY: Cold Spring Harbor Laboratory.

Sára, M. \& Sleytr, U. B. (2000). S-Layer proteins. J Bacteriol 182, 859-868.

Sillanpää, J., Martínez, B., Antikainen, J. \& 9 other authors (2000). Characterization of the collagen-binding S-layer protein CbsA of Lactobacillus crispatus. J Bacteriol 182, 6440-6450.

Sleytr, U. B. \& Sara, M. (1997). Bacterial and archaeal S-layer proteins: structure-function relationships and their biotechnological applications. Trends Biotechnol 15, 20-26.

Stackebrandt, E., Frederiksen, W., Garrity, G. M. \& 10 other authors (2002). Report of the ad hoc committee for the re-evaluation of the species definition in bacteriology. Int J Syst Evol Microbiol 52, 1043-1047.

Stiles, M. E. \& Holzapfel, W. H. (1997). Lactic acid bacteria of foods and their current taxonomy. Int J Food Microbiol 36, 1-29.

Tannock, G. W., Tilsala-Timisjarvi, A., Rodtong, S., Ng, J., Munro, K. \& Alatossava, T. (1999). Identification of Lactobacillus isolates from the gastrointestinal tract, silage, and yoghurt by 16S-23S rRNA gene intergenic spacer region sequence comparisons. Appl Environ Microbiol 65, 4264-4267.

Vancanneyt, M., Neysens, P., De Wachter, M. \& 8 other authors (2005). Lactobacillus acidifarinae sp. nov. and Lactobacillus zymae sp. nov., from wheat sourdoughs. Int J Syst Evol Microbiol 55, 615-620.

Ventura, M., Callegari, M. L. \& Morelli, L. (2000). S-layer gene as a molecular marker for identification of Lactobacillus helveticus. FEMS Microbiol Lett 189, 275-279.

Ventura, M., Canchaya, C., Meylan, V., Klaenhammer, T. R. \& Zink, R. (2003). Analysis, characterization, and loci of the tuf genes in Lactobacillus and Bifidobacterium species and their direct application for species identification. Appl Environ Microbiol 69, 6908-6922.

Walter, J., Hertel, C., Tannock, G. W., Lis, C. M., Munro, K. \& Hammes, W. P. (2001). Detection of Lactobacillus, Pediococcus, Leuconostoc, and Weissella species in human feces by using groupspecific PCR primers and denaturing gradient gel electrophoresis. Appl Environ Microbiol 67, 2578-2585.

Zeigler, D. R. (2003). Gene sequences useful for predicting relatedness of whole genomes in bacteria. Int J Syst Evol Microbiol 53, 1893-1900. 